\title{
IMPLEMENTING TASK BASED LANGUAGE TEACHING (TBLT) INSTRUCTION TO IMPROVE STUDENTS' SPEAKING PARTICIPATION IN ISLAMIC BOARDING SCHOOL OF MAULANA MALIK IBRAHIM, STATE ISLAMIC UNIVERSITY OF MALANG
}

\author{
Khusnul Khotimah \\ www.khusnul@stmik-yadika.ac.id \\ STMIK Yadika Bangil
}

\begin{abstract}
English speaking ability has long been considered as one of the most crucial materials for a bilingual program in Islamic Boarding School of Maulana Malik Ibrahim, State Islamic University of Malang. Since students of that Islamic Boarding School are demanded to be able to communicate in English, motivation and training to comprehend in mastering it are needed. However, some students consider speaking as the most difficult one since it needs great courage as well as preparation to produce the language. Either beginner or advanced students participate passively when joining Sobaghul Lughoh program. The researcher is interested conducting a research for Advance class because they are considered having good capability either verbal or oral in English but they seem passive participating in the class. The researcher uses Classroom Action Research (CAR) to analyze and solve the problems faced by the Advance class. Furthermore, the researcher concerns on their speaking participation rather than other skills because speaking is productive skill which can be directly and empirically observed. The result is the students enthused joining the program and participated much in doing the task. Finally, Implementing Task Based Language Teaching (TBLT) instruction in Sobaghul Lughoh Program has showed conclusion that this method is appropriate to be applied. This strategy is able to improve students' speaking participation in class. Their participation in completing tasks, discussion and conversation shows that they are active and enthusiasm following the program.
\end{abstract}

Key Words: TBLT, Speaking, Sobaghul Lughoh Program

\section{INTRODUCTION}

English speaking ability has long been considered as one of the most crucial materials for a bilingual program in Islamic Boarding School of Maulana Malik Ibrahim, State Islamic University of Malang. During the past decade, the principles of that university have been addressing the necessity of being able to communicate English effectively. Furthermore, the principal has stated that Islamic Boarding School of this university is the starting point to learn English which focus on improving the students' English ability. Many activities in the Islamic Boarding School are conducted to develop students' English mastery which are associated with their future educational opportunities such as university's program (Intensive English Course), future career and socializing with people around the world as the preparation of this university's aim to be an international university.

The students are prepared to master in English even all of them are not from English department. Variety of students is behaved differently based on their capability in English. Hence, the programs done are to support them to learn English well. One of the most superior bilingual programs which become the center of learning English and support language environment is Sobaghul Lughoh program. The students are divided into three groups classification based on their background knowledge and capability in English. They are advanced, intermediate and beginner class.

The classification of class is 
decided after doing an English placement test in the first meeting in the first semester. Then, the students are classified with groups which have equal capability in English. Beginner class is consisted of students who are lack of English, either oral or verbal language. Intermediate class is consisted of students who have capability in English but they have bit problems such as in grammatical when constructing sentences or difficulties uttering ideas when speaking although they understand. The last is advance class which is consisted of students who master in English, either verbal or oral language. Then, each class in each classification of class is guided with one tutor as the teacher, guide and/ or instructor.

The researcher is interested conducting a research for Advance class because the students of this class are considered having good capability either verbal or oral in English. Unfortunately, most of them are passive joining Sobaghul Lughoh program. They seem not spirit when coming in the class. Hence, doing Classroom Action Research (CAR) is an appropriate to analyze and solve the problems faced by the Advance class. Furthermore, the researcher concerns on their speaking participation rather than other skills because speaking is productive skill which can be directly and empirically observed.

In that case, TBLT is considered able to build an interactive teaching in order to make students' learning more active, efficient and easy to practice the materials. The researcher tries to match between types of speaking task according to Brown's book and students of Advance capability. There are basic types of speaking and the researcher chooses to use types of interactive speaking class which the tasks consist of role plays, discussions and games. These tasks are appropriate for the advance class students because they can explore their speaking English ability and interact with their friends within group discussion.

TBLT has taken a central role in many language classrooms for the past several decades. Nassaji and Fotos provide four important features of TBLT. First, TBLT is student-centered, and it largely focuses on communication over accuracy. Second, lessons revolve around tasks that challenge students to stretch beyond their language levels while being exposed to realistic situations. Third, TBLT has been adopted by many instructors worldwide as a preferred approach to teach language because it allows learners to develop authentic language. Last, TBLT provides a flexible framework for language instructors to create a classroom that facilitates second language acquisition.

Students will think about which one is better, to talk much with many errors or to think more with better result. It can be answered when the aims of speaking is clearly stated, that is to build meaningful communication. In this case, to encourage students to talk as much as possible to convey the messages of communication is more important rather than to let them think about the grammar rules they use. In this research, the researcher will show that TBLT is an effective way to motivate students to communicate or interact with their friends freely in Islamic Boarding School because this method provide them to use their second language. Furthermore, the researcher will also examine the application of TBLT materials in the class.

There are several researchers who conduct research about Task-Based Instruction. First is Hyde (2013). His paper examines both the history and characteristics of Business English and TBLT, and discusses how TBLT is suited for Business English instruction. TBLT is compared to more traditional, teacher 
centered approaches and methods. The basic stages of TBLT are examined and discussed with emphasis on when the teacher can focus on form and/or meaning. Two sample lesson plans developed for post-graduate university students are included in the paper to show how TBLT can be used in the Business English classroom. The lesson plans focus on the business tasks of writing business emails and writing an itinerary. These TBLT lessons plans can be adapted for use in Business English classrooms and illustrate how TBLT can be used to teach Business English by using pedagogical tasks that mirror real world business tasks. This makes the lesson plan more meaningful to the students, and allows them to use the business abilities and language taught outside of the classroom. These basic lessons can also be used as templates to teach additional business tasks including: writing business letters, giving presentations, and preparing business reports.

Second is Dailey (2009). This paper has discussed positive and negative aspects of certain characteristics TBL represents, the different views and opinions that TBL has attracted, and the problems if introduced into Korean classrooms. He strongly believes that TBL has its valuable points and is a new, exciting, and interactive method to improve communicative competence. However, despite the Korean government's determination to implement a more communicative approach to teaching in public school classrooms across Korea, the strongly Confusion culture of Korea with its teacher-centered, passive educational traditions is in many ways opposed to the leaner-centered ideals of TBL. The successful introduction of TBL would require more than just a change in government policy; it will require a distinctly different mindset on the part of Korean educators in order to revise the method to coincide with Korean standards of education.

According to those previous researches, the researcher would like to conduct a research about the implementing Task-Based Language Teaching (TBLT) instruction to improve students' speaking participation in Sobaghul Luhghoh program conducted in Islamic boarding school of Maulana Malik Ibrahim, State Islamic University of Malang, especially to describe the influence of the task to the development

\section{METHOD}

The research design employed for this research is CAR (Classroom Action Research). The research is addressed for Advanced Class which consists of 14 students. This class was chosen because basically they have good speaking ability but most of them have low self-motivation to learn English in Sobaghul Lughoh program.

\section{Stages of TBLT Lesson}

TBLT is considered to able to build an interactive teaching in order to make students' learning more active, efficient and easy to practice the materials. It is important to establish a good atmosphere in the classroom. There are procedures to teach speaking ability by using Task Based Language Teaching (TBLT) as follow:

\begin{tabular}{ll}
\hline Pre-Task & Introduction of task and topic: Preparation of task \\
Task Cycle & Task: Students work in pairs or groups \\
& Planning: Students prepare to report (oral or written) \\
& Report: Groups or pairs present to the class \\
Language & Analysis: Students examine specific language features \\
Focus & Practice : Teacher has taught students to practice new materials \\
\hline
\end{tabular}




\section{Pre-Task Stage of TBLT}

During the pre-task stage, teachers introduce the task. At this stage, they can also provide valuable background information to scaffold the students' learning. New vocabulary or phrases may be introduced, but the focus of the pre-task stage is to prepare the students and attract their interest to the task and subject. This pre-task stage takes place at the beginning or introduction of the lesson, or even the lesson before.

\section{Task Cycle}

First task cycle is task. According to Willis, the task is often performed working with a partner or small group, and the students use the language they already have to try to communicate in the target language. The goal of the task is to encourage meaningful communication that leads to language learning and the completion of the task.

Second is planning. The students work together to prepare what they will report back to the class. It gives them a chance to think about the language. Ideally, the students are given several options on how they chose to report their task. For example, they may be able to report verbally or in written form. The teacher should be available to help with language accuracy at this stage and can visit each group to offer language advice if solicited. Students could also use dictionaries and the internet to check for accuracy and should be allowed to use their native language to interact.

Last is reporting stage, groups, often using a spokesperson, communicate their findings to the class. The reporting method will vary depending on the task but somehow the group will complete the classroom task and share their work with the teacher and other groups. The reporting could be done by the entire group or a spokesperson.

\section{Language Focus}

The final section of the TBLT framework is the language focus when the class often focuses on forms. First, in the analysis stage, students are encouraged by their teachers to analyze features of the language that they used to complete the task. Teachers may focus on one or more language features, so the role of the teacher at this stage can be as a traditional grammar teacher giving explicit instruction.

The practice stage is the last stage in TBLT lessons. Teachers provide an activity to practice the features of the language that the students have analyzed. Willis states that TBLT is primarily concerned with a focus on meaning, but at this final stage there is often also a focus on form. Students are taught the finer points of the forms which they explored during the task.

\section{FINDING}

The researcher tried to collect the preliminary study before carrying out this research. To enrich the data, the researcher observed the teaching learning process and analyzed how the condition of Sobaghul Lughoh program was. Besides, the researcher also interviewed the teacher of this program and gives questionnaire for students to gain the data. Then, the researcher discussed the result of the interview and questionnaire with the teacher who was as the collaborator of this research. The result of preliminary studies that was found some field problems, as follows: 


\begin{tabular}{|c|c|}
\hline No & Problems \\
\hline 1 & The students felt bored with morning regular activities \\
\hline 2 & $\begin{array}{l}\text { Students were not given a chance to speak, but most of time just heard what the } \\
\text { teacher explained }\end{array}$ \\
\hline 3 & The way how the teacher explained sometimes make students bored \\
\hline 4. & The guidance book provide few interesting materials \\
\hline 5 & $\begin{array}{l}\text { Most students have low motivation (sleepy and lazy) joining the program because it } \\
\text { is conducted in early morning }\end{array}$ \\
\hline 6 & Some students feel shy or have no confidence when speaking English in the class \\
\hline $7^{\circ}$ & $\begin{array}{l}\text { The teacher sometimes gave difficulties to find the method how to teach the } \\
\text { students }\end{array}$ \\
\hline 8 & $\begin{array}{l}\text { Sometimes the students could not focus on the teacher explanation when they face } \\
\text { and hear other class making noisy and having fun with their class activities. }\end{array}$ \\
\hline
\end{tabular}

The aims of implementing Task Based Language Teaching (TBLT) is to improve speaking participation, the researcher would like to solve the problem in Sobaghul Lughoh program class who was usually silent and passive when receiving the materials from the teacher. Before conducting this research, the students were passive in joining Sobaghul Lughoh program. However, after implementing TBLT instruction, the students speaking participation in class increase more than 10 students active participating in class. Based on the students' progress of implementing TBLT, there was improvement of the students speaking participating in joining Sobaghul Lughoh program.

\section{DISCUSSION}

This research shows that implementing Task Based Language Teaching (TBLT) is one of better ways to learn English when it is applied in Sobaghul Lughoh program. This approach motivates students to have richer language. The Task-based material, with its richer input and opportunities for analysis of texts, allows learners to notice what they want, need, or are ready to learn features of discourse. The strength of TBLT is that it provides the students to have the opportunities to make use of background knowledge resources they have either from previous knowledge or the pre-task input. Through interactions or negotiation of meanings, students can eventually develop greater fluency in communication.

Implementing Task-based learning is advantageous for student of Sobaghul Lughoh program, moreover for advance class because it is more student-centered and allows for more meaningful communication. Students can speak freely with their speaking ability they have. Although the teacher may present language in the pre-task, the students are ultimately free to use what grammar constructs and vocabulary they want. This allows them to use all the language they know and learn, rather than just the 'target language' of the lesson.

When applying this approach, the researcher and the teacher pay attention in developing a curriculum which is orientated to the syllabus. Then, to achieve it, what the researcher and the teacher done is doing needs analysis, objectives of the task, developing the task to determine the students' achievement of the course objectives, creating the task materials and teach the course. Finally, the result of the implementing Task Based Language 
Teaching (TBLT) instruction to improve speaking participation in Sobaghul Lughoh program produces a good result for the students. Not only improve students' vocabularies in speaking skill, but also their participation in joining this program increase. The result is showed by their enthusiasm to participate in each meeting. Most of them become talkative and enthuse joining the program.

Furthermore, the choice of task also influence to the response of the students. It was very crucial for the quality and quantity of interaction.

Thus, the ability of teachers to adjust the difficulty of tasks may be able to reduce reluctant students to speak more. Task Based Language Teaching has attracted the attention of students in Sobaghul Lughoh program. It has reduced the teacher-dominated and form-oriented methods. Therefore, it can be concluded that tasks should have not only focus on meanings but also on forms. By providing tasks, students become active participating in doing the task. They also have an adequate chance to employ different skills in English for the purpose of communication. The task given is also flexible and can be adjusted and adopted to suit the language proficiency of learners. Thus, the students enjoy doing the task because the tasks are familiar with their background knowledge.

\section{CONCLUSION}

Implementing of Task Based Language Teaching (TBLT) instruction in the context of Sobaghul Lughoh Program has showed conclusion that this method is appropriate to be applied. This strategy is able to improve students' speaking participation in joining the program. Their participation in completing the task, discussion and conversation shows that they are active and enthusiasm following the program.

The successful of implementing of
TBLT in Sobaghul Lughoh program is supported by some aspects. The aspects are the teacher' task explanation is clearly stated, motivating students exploring their language, class management, providing a chance for students to ask problem faced and balancing active and passive students in doing task.

\section{REFERENCES}

Brown, H. Douglas. 2007. Teaching by Principles, An Interactive Approach to Language Pedagogy. USA : Pearson Education, Inc.

Dailey, Aja. 2009. Implementing TaskBased Language Teaching in Korean Classrooms. University of Birmingham

Ducker, Nathan. 2012. Enriching the Curriculum with Task-Based Instruction.

Ellis, R. (2003). Task-based Language Learning and Teaching. Oxford: Oxford University Press.

Ellis, R. (2009). Task-based language teaching: sorting out the misunderstandings,

International Journal of Applied Linguistics, 19(3), 221 - 246.

Hosseini, Hossein Shams \& Rahbar, Mohhammad. 2012. A New Trend in Education: Task-Based Methodology for Teacher/ Learners. Singapore: IACSIT Press- International Conference on Management and Education Innovation IPEDR vol.37

Hyde, Colleen. 2013. Task-Based Language Teaching in the Business English Classroom. University of Wisconsin-River Falls

Kotaka, Masae. 2012. Task-Based Language Teaching (TBLT) and 
E-Link Journal

Vol. 5 No. 2 (2018)

the Japanese English Classroom.

Kumaravadivelu, B. (2003). Beyond Methods: Macro strategies for Language Teaching. New Haven: Yale University Press.

Latief, M. A. 2009. Classroom Action Research in Language. State University of Malang: Malang

Malihah, Noor. 2010. The Effectiveness of Speaking Instruction through TaskBased Language Teaching. Salatiga: English Department of

p-ISSN: 2085-1383; e-ISSN: 2621-4156

Education Faculty State Islamic Studies Institute (STAIN) of Salatiga

Nassaji, Hossein and Sandra Fotos. 2011.

Teaching Grammar in Second

Language Classrooms: Integrating

Form-Focused Instruction in

Communicative Context. New

York: Routledge.

Nunan, D. 1989. Designing Tasks for the Communicative Classroom. Cambridge:Cambridge University Press. 